\title{
Effect of Spacing and Fertilization on the Yield of Potatoes
}

\author{
Pablo Landrau, Jr., Juan Pastor Rodriguez, George Samuels, \\ Severiano Alers Alers, and $R$. Gandia Caro ${ }^{1}$
}

\section{INTRODUCTION}

At present the cultivation of potatoes in Puerto Rico is limited to a small acreage. The Island of Puerto Rico imports practically all of the potatoes that it consumes. During the years 1952 and 1953, it imported 735,379 and 914,913 one-hundred-pound bags of potatoes, respectively. The yields of the varieties tested and cultivated in the Island during the past 10 years were so low that their production on a commercial scale was economically impossible. This low yield was due principally to the susceptibility of the potato varieties to early and late blight. Recently the introduction of the Kennebec variety, which proved resistant to both early and late blight, rendered the possibility of growing potatoes commercially on the Island so important that there was need to gather information about the quantities of the major fertilizer elements (N-P-K) required to obtain maximum production from soils devoted to the crop. It was decided also to determine the best distance between plants, and whether closer spacing required higher rates of fertilizer.

\section{EXPERIMENTAL PROCEDURE}

The spacing and fertilizer study with potatoes consisted of three experiments in different areas of the Island which varied as to soil type, elevation, and amount of rainfall. The Corozal experiment, (elevation 400 feet) was conducted on a Lares clay, a lateritic acid clay ( $\mathrm{pH} 4.5$ ) of the terrace and alluvial fans of Puerto Rico, cropped mainly to sugarcane and pineapples. The Aibonito experiment (elevation 2,000 feet) was established on a Juncos clay, an acid soil ( $\mathrm{pH}$ 6.5) of the foothills that occurs in association with the extensive Múcara soils of the mountainous area and also in association with the soils of the valleys. This soil is cropped to sugarcane, subsistence crops, and tobacco. The Isabela experiment (elevation 275 feet)

${ }^{1}$ Assistant Agronomist, Associate Agronomist, Agronomist, and Research Assistant in Agronomy, respectively, Agricultural Experiment Station, University of Puerto Rico, Río Piedras, P. R. The authors wish to express their appreciation to the following for their fine cooperation in the field: A. S. Amy, Associate Agronomist, in Charge; H. Gandia Díaz, Associate Horticulturist, in Charge; R. Olivencia, Research Assistant in Plant Breeding; A. Riollano, Agronomist, in Charge, and R. Abrams, Research Assistant in Agronomy, all of the Agricultural Experiment Station of the University of Puerto Rico. 
was planted on a Coto clay, a friable soil of the coastal plains, slightly acid in reaction ( $\mathrm{pH}$ 6), and devoted mainly to sugarcane and other irrigated crops, such as peppers, tomatoes, tobacco, cotton, and corn.

The spacing used in all the experiments were $6,9,12,15$, and 18 inches between plants. The fertilizer treatments for the three experiments consisted of varying amounts per acre of nitrogen $(\mathrm{N})$, phosphoric acid $\left(\mathrm{P}_{2} \mathrm{O}_{5}\right)$, and potash $\left(\mathrm{K}_{2} \mathrm{O}\right)$. The rates applied per acre of these fertilizer substances are presented later in tables 1 to 3.

The Corozal experiment was planted on January 18, 1954, using plots of five rows, 2 feet apart and 20 feet long, or approximately one two-hundred-seventeenth of an acre in size. The fertilizer was applied in the hole and covered with soil 1 day before planting. The experiment was harvested on April 12, 1954, after 85 days of growth.

The Aibonito experiment was planted on December 16, 1953, and fertilized 12 days after planting. The fertilizer was applied in bands about 2 inches deep at a distance of 3 inches from the small potato plants. The plots consisted of four rows, 3 feet apart and 20 feet long, or approximately one eighty-one hundredth of an acre in size. The crop was harvested on March 29, 1954, after 104 days of growth.

The Isabela experiment was fertilized on December 30, 1953, and planted 6 days later. The fertilizer was applied in the hole and covered with soil. The plots consisted of five rows, 3 feet apart by 17 feet long, or approximately one one-hundred-seventieth of an acre in size. The crop was harvested on April 7, 1954, after 94 days of growth.

The experimental design for all these experiments was a split-plot one in which the spacing between plants was studied in the whole plots. All treatments were replicated four times.

The variety planted was Kennebec, a seedling introduced in Puerto Rico from the United States about 5 years ago. This seedling proved to be resistant to early and late blight, two serious diseases to which the varieties of potatoes previously tested in the Island proved susceptible.

The potatoes were treated with a solution of 2-chloroethanol, $60 \mathrm{ml}$. per gallon of water for 5 minutes, to increase the germinating power of the potato seed pieces by breaking the dormancy period. After the potato seed were treated, scattered on the floor, and allowed to dry, they were cut into small pieces. The size of seed depended on the number of eyes presented and the size of the potato itself. The scars made on the potatoes were allowed to heal, before planting.

\section{EXPERIMENTAL RESULTS}

The results of the effect of spacing and different fertilizer treatments on the yields of potatoes are presented in tables 1 to 3 . 
TABLE 1.-Influence of spacing and major-element fertitizers on the yield of potatoes in the Corozal experiment on Lares clay

\begin{tabular}{|c|c|c|c|c|c|c|c|c|c|}
\hline \multirow{2}{*}{ Treatment No. } & \multicolumn{3}{|c|}{ Treatments per acre of- } & \multicolumn{5}{|c|}{$\begin{array}{l}\text { Mean yield of potatoes per acre for } \\
\text { spacing indicated- }\end{array}$} & \multirow{2}{*}{$\begin{array}{c}\text { General } \\
\text { fertilizer } \\
\text { means }\end{array}$} \\
\hline & $\mathrm{N}$ & $\mathrm{P}_{2} \mathrm{O}_{5}$ & $\mathrm{~K}_{2} \mathrm{O}$ & $6 \mathrm{in.}$ & 9 in. & $12 \mathrm{in.}$ & $15 \mathrm{in.}$ & $18 \mathrm{in.}$ & \\
\hline & Pounds & Pounds & Pounds & Crot. & Cwt. & Cwt. & Cwit. & Cwt. & Cwt. \\
\hline 1. & 0 & 100 & 100 & 63.8 & 53.7 & 55.7 & 51.6 & 45.3 & 54.0 \\
\hline 2 & 100 & 0 & 100 & 52.3 & 54.0 & 37.8 & 35.6 & 33.6 & 42.6 \\
\hline 3 & 100 & 100 & 0 & 61.6 & 64.1 & 66.2 & .61 .8 & 37.1 & 58.2 \\
\hline 4 & 100 & 100 & 100 & $95: 0$ & 51.7 & 63.6 & 62.2 & 55.2 & 65.5 \\
\hline 5 & 150 & 150 & 150 & 75.7 & 55.6 & 59.7 & 59.7 & 67.2 & 63.6 \\
\hline 6 & 200 & 200 & 200 & 78.6 & 58.9 & 57.6 & 54.4 & 54.6 & 60.8 \\
\hline \multicolumn{4}{|c|}{ General spacing means .......... } & 71.2 & 56.4 & 56.8 & 54.2 & 48.8 & \\
\hline
\end{tabular}

Least significant differences between:

-percent 1-percent

Any 2 general means of fertilizer treatments . . . . . . . . . . . . $13.4 \quad 17.8$

Any 2 general means of spacing treatments . . . . . . . . . . . $17.0 \quad 23.9$

Any 2 means of individual fertilizer-spacing treatments. . . . . . $30.0 \quad 39.8$

Any 2 means of any other spacing and fertilizer experiments... $32.2 \quad 43.4$

TABLI 2.-Influence of spacing and major-element fertilizers on the yield of potatoes in the Isabela experiment on Coto clay

\begin{tabular}{|c|c|c|c|c|c|c|c|c|c|}
\hline \multirow{2}{*}{$\begin{array}{l}\text { Treatment } \\
\text { No. }\end{array}$} & \multicolumn{3}{|c|}{ Treatments per acre of- } & \multicolumn{5}{|c|}{$\begin{array}{c}\text { Mean yield of potatoes per acre for spacing } \\
\text { indicated- }\end{array}$} & \multirow{2}{*}{$\begin{array}{c}\text { General } \\
\text { fertilizer } \\
\text { means }\end{array}$} \\
\hline & $\mathrm{N}$ & $\mathrm{P}_{2} \mathrm{O}_{5}$ & $\mathrm{~K}_{2} \mathrm{O}$ & $6 \mathrm{in.}$ & 9 in. & $12 \mathrm{in.}$ & 15 in. & $18 \mathrm{in.}$ & \\
\hline & Pounds & Pounds & Pounds & Cwt. & Cwot. & Cwt. & Cwt. & Cwt. & \\
\hline 1 & 0 & 100 & 100 & 154.0 & 150.5 & 142.7 & 120.9 & 108.2 & 135.2 \\
\hline 2 & 100 & 0 & 100 & 128.9 & 124.4 & 97.7 & 96.1 & 69.2 & 103.3 \\
\hline 3 & 100 & 100 & 0 & 168.6 & 160.4 & 148.1 & 136.0 & 124.5 & 147.5 \\
\hline 4 & 100 & 100 & 100 & 197.3 & 158.6 & 185.1 & 150.2 & 145.0 & 167.2 \\
\hline 5 & 150 & 150 & 150 & 189.6 & 168.6 & 141.1 & 129.5 & 109.0 & 147.6 \\
\hline 6 & 200 & 250 & 200 & 173.1 & 160.3 & 155.5 & 129.7 & 110.0 & 145.7 \\
\hline \multicolumn{4}{|c|}{ General spacing means.. } & 168.6 & 153.8 & 145.0 & 127.1 & 111.0 & \\
\hline
\end{tabular}

Least significant differences between:

-percent 1-percent

Any 2 general means of fertilizer treatments . . . . . . . . . . $24.0 \quad 31.7$

Any 2 general means of spacing treatments............... $23.2 \quad 32.5$

Any 2 means of individual fertilizer spacing treatments...... $53.7,71.3$

Any 2 of any other spacing and fertilizer treatments . . . . . . $72.6 \quad 54.2$ 
TABLE 3-Influence of spacing and major-element fertilizers on the yield of potatoes in the Aibonito experiment on Juncos clay

\begin{tabular}{|c|c|c|c|c|c|c|c|c|c|}
\hline \multirow{2}{*}{ Treatment No. } & \multicolumn{3}{|c|}{ Treatment per acre of- } & \multicolumn{5}{|c|}{$\begin{array}{c}\text { Mean yield of potatoes per acre for spacing } \\
\text { indicated- }\end{array}$} & \multirow{2}{*}{$\begin{array}{l}\text { General } \\
\text { fertilizers } \\
\text { means }\end{array}$} \\
\hline & $\mathrm{N}$ & $\mathrm{P}_{2} \mathrm{O}_{5}$ & $\mathrm{~K}_{2} \mathrm{O}$ & $6 \mathrm{n}$. & 9 in. & 12 in. & $15 \mathrm{in.}$ & 18 in. & \\
\hline & Pounds & Pounds & Pounds & Cwt. & Cwt. & Cwt. & $C w t$. & Cwol. & Cwt. \\
\hline 1 & 0 & 100 & 100 & 71.0 & 55.6 & 54.5 & 41.7 & 29.5 & 50.5 \\
\hline 2 & 100 & 0 & 100 & 68.0 & 51.2 & 48.6 & 38.9 & 36.3 & 48.6 \\
\hline 3 & 100 & 100 & 0 & 75.6 & 67.2 & 53.8 & 49.3 & 42.8 & 57.7 \\
\hline 4 & 100 & 100 & 100 & 77.7 & 57.4 & 56.2 & 43.6 & 42.8 & 55.5 \\
\hline 5 & 150 & 150 & 150 & 80.9 & 68.8 & 58.4 & 38.0 & 36.0 & 56.4 \\
\hline 6 & 200 & 200 & 200 & 72.6 & 63.6 & 52.6 & 45.4 & 41.1 & 55.0 \\
\hline \multicolumn{4}{|c|}{ General spacing means........... } & 74.3 & 60.6 & 54.0 & 42.8 & 38.1 & \\
\hline
\end{tabular}

Least significant differences between:

- 5-percent 1-percent

Any 2 general means of fertilizer treatments . . . . . . . . . .

Any 2 general means of spacing treatments................

$\begin{array}{llll}\text { Any } 2 \text { means of individual fertilizer spacing treatments........ } & 11.9 \quad 15.8\end{array}$

$\begin{array}{llll}\text { Any } 2 \text { means of any other spacing and fertilizer treatments..... } & 13.2 & 17.8\end{array}$

\section{EFFECT OF MAJOR FERTILIZER ELEMENTS ON YIFLDS}

\section{Nitrogen}

In none of the three experiments did the applications of nitrogen have consistent significant effects on potato yields.

\section{Phosphorus}

There was a definite response in yield of potatoes from the use of phosphorus fertilizer. The use of 100 pounds of phosphorus $\left(\mathrm{P}_{2} \mathrm{O}_{5}\right)$ per acre proved to be sufficient for all three experiments (see tables 1,2 , and 3 , treatments 2 and 4). No additional response was obtained by increasing the phosphorus application beyond 100 pounds of $\mathrm{P}_{2} \mathrm{O}_{5}$ per acre. The response in yield was significant at the 1-percent level for the Corozal and Isabela experiments and at the 5-percent level for the Aibonito experiment.

\section{Potassium}

The application of potash failed to increase yields significantly in any one of the three experiments (see tables 1,2 , and 3 , treatments 3 and 4 ).

The response of potatoes to the three major fertilizer elements for all three experiments is presented in a graphic form in figure 1. The Aibonito and Corozal experiments followed more or less the same trend in relation 
to the response to phosphorus, then nitrogen, and last potassium. The potato made better use of all three fertilizer elements on the Coto clay soil at Isabela than on the Lares clay and the Juncos clay at Corozal and Aibonito, respectively.

\section{EFFECT OF DIFFERENT PLANTING DISTANCES}

The results of different planting distances are also presented in tables 1,2 , and 3. Spacing definitely influenced the yield of the potato.

The highest yields were obtained when the potatoes were planted at a distance of 6 inches between plants and decreased gradually as the planting distance increased. The highest yields were obtained when the potato seed pieces were planted 6 inches apart in the row in all three experiments; at Corozal a significantly higher yield was obtained at the 6-inch than at the 15and 18-inch distances. At Aibonito the yields obtained at the 6-inch planting distance were highly significantly greater than those obtained at the other four spacings used (see table 3 , general means). The yields obtained at Isabela showed that the 6 -inch was superior to the 12 -inch spacing at the 5-percent and to the 15- and 18-inch spacings at the 1-percent level (see table 2).

The high production of potatoes is influenced not only by the fertilizer

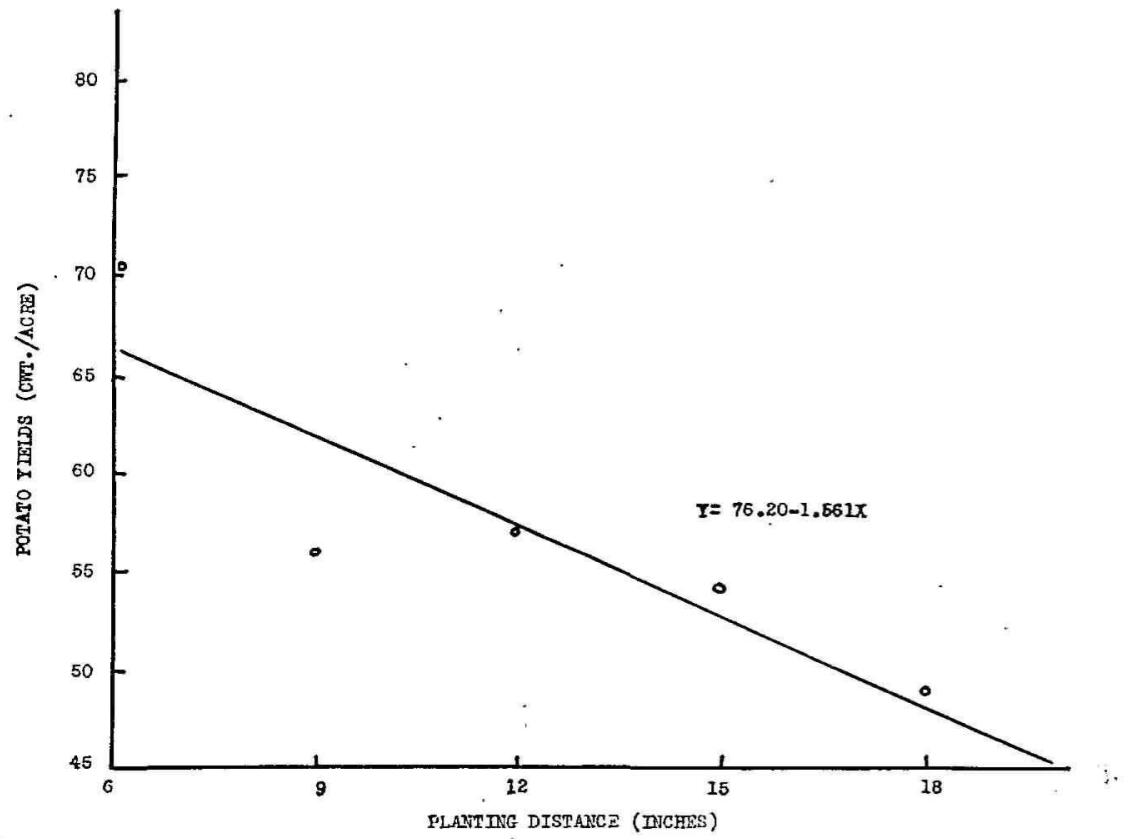

Frg. 1.-Effect of different planting distances on potato yields at Corozal. 
used but also by the planting distance. The results of three spacing experiments are presented in figures 1, 2, and 3. The graphs show that a definite linear relationship exists between yields of potatoes per acre and the planting distance; the yields per acre decreased with increased distance of planting. The regression equations obtained were: For the Corozal experiment $Y=76.20-1.561 X$; for Isabela $Y=197.85=4.731 X$; and for Aibonito $Y=90.07-3.008 X$, where $Y$ is the yield of potatoes in hundred-weights per acre and $X$ is the spacing in inches between plants in the row. The régressions of distance of planting on yield of potatoes per acre were very significant at the 1-percent level in all three cases.

\section{FERTIUIZER-PLANTING DISTANCE INTERACTION}

There were no significant interactions between planting distances and fertilizer applications. The potatoes planted at a distance of 6 inches did not require any more fertilizer than did those at the extreme distance of 18 inches, despite the fact that there were three times as many plants present at the closer planting distance. The use of additional fertilizer above the regular rates (treatments 5 and 6 as compared to treatment 4 ). did not lead to higher yields. It appears that, at least under conditions similar to

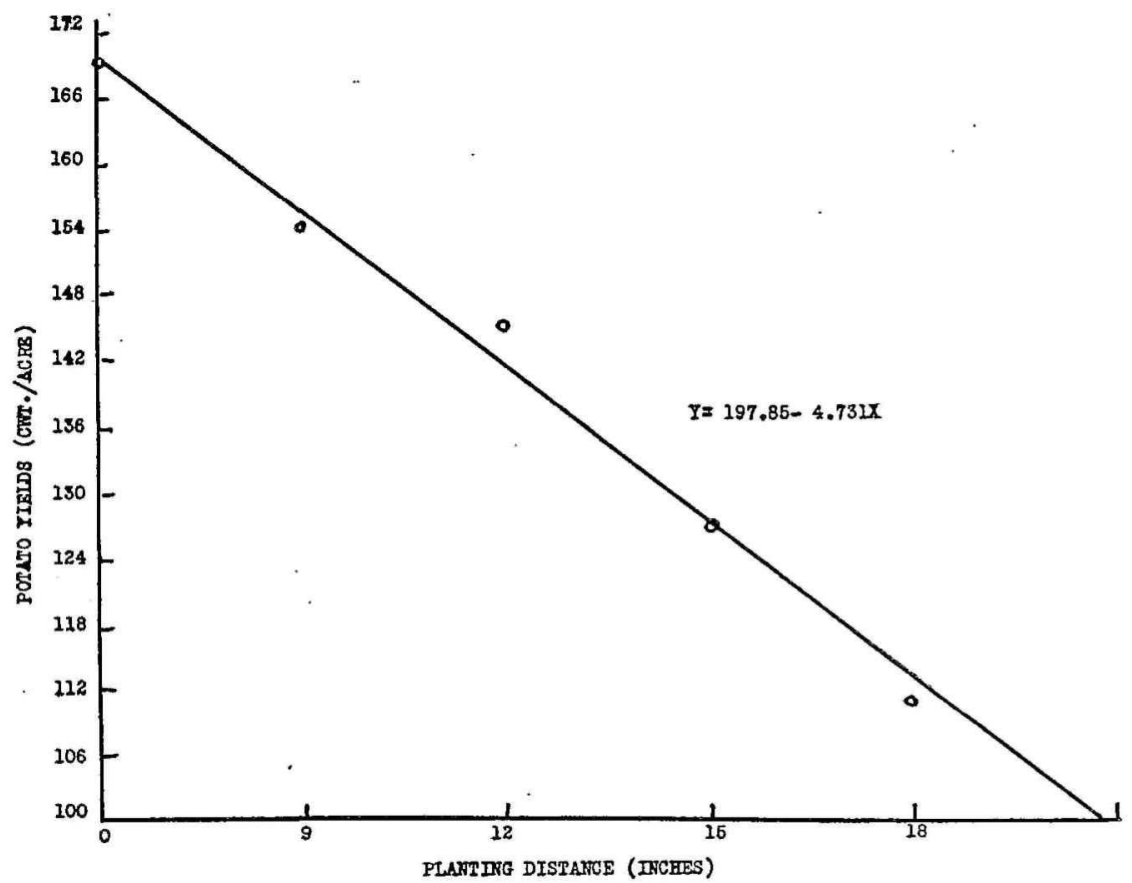

FIG. 2.-Effect of different planting distances on potato yields at Isabela. 
those of these experiments, maximum yields would be obtained by using a 6-inch distance between plants in the row and applying only 100 pounds of $\mathrm{P}_{2} \mathrm{O}_{5}$ per acre.

\section{RELATIVE RESPONSE TO FERTITIZERS AND SPACING}

Potatoes, like all other crops, require plant food for their development and growth. The quantities of the different fertilizer elements that have to be applied to any soil depend on the actual amounts of these elements which the soil itself is able to provide to the crop. The available amounts of these elements in the soil depend on the quantities already present there, the chemical form in which they are present, and the weather during the growth period. Excessive drought or rainfall during the growth period is detrimental to the normal growth of the plant, even if the soil contains optimum amounts of the nutritive elements. Table 4 and figure 4 present the relative response of the potato to the fertilizer elements and the six different spacings in the form of percentage reduction in yields due to the omission of one fertilizer element or to increased spacing.

The calculations for reduction in yield caused by spacing were made by using the highest yields obtained, which corresponded to the 6 -inch spacing, as the basis, and comparing these with the others included in the study.

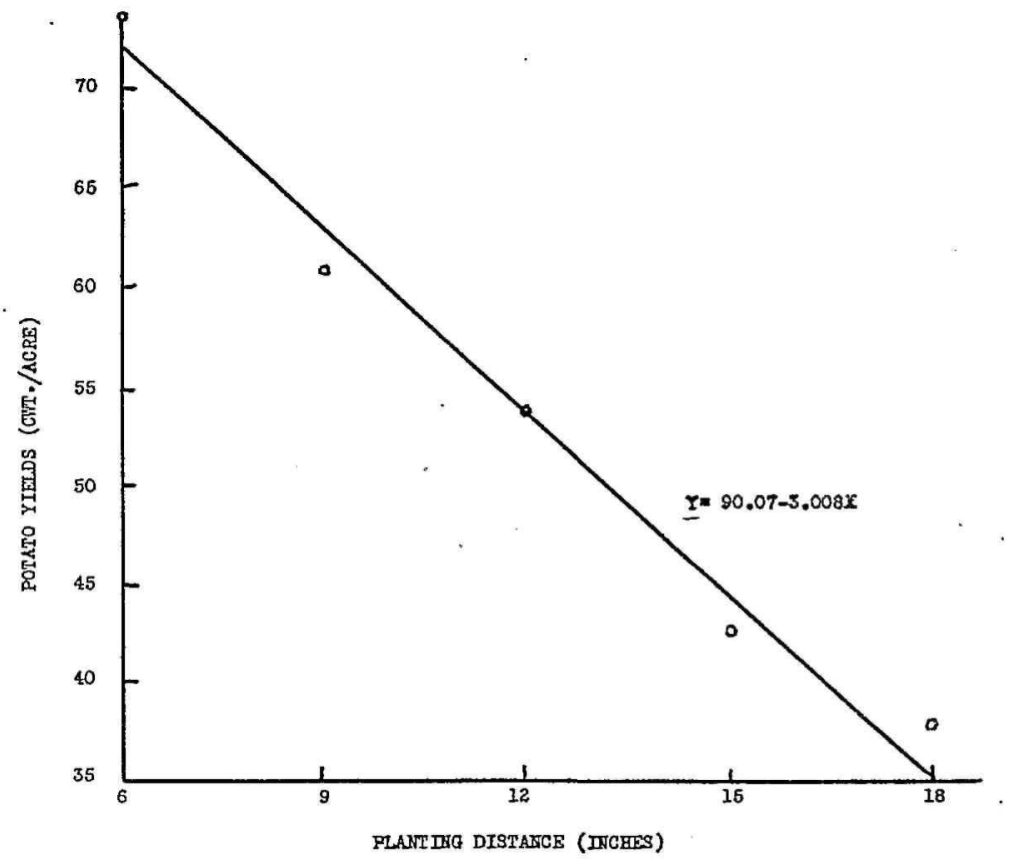

FIG. 3.-Effect of different planting distances on potato yields at Aibonito. 
TABLI 4.-The percentage reduction in yield of potatoes attributable to increased spacing or to the omission of nitrogen, phosphorus, or potassium

\begin{tabular}{|c|c|c|c|c|c|c|c|c|}
\hline \multirow{2}{*}{ Place of experiment } & \multicolumn{5}{|c|}{ Reduction in yield due to spacing of -1} & \multicolumn{3}{|c|}{$\begin{array}{l}\text { Reduction in yield from } \\
\text { omission of -2 }\end{array}$} \\
\hline & 6 inches & $\begin{array}{c}9 \\
\text { inches }\end{array}$ & $\begin{array}{l}12 \\
\text { inches }\end{array}$ & $\begin{array}{c}15 \\
\text { inches }\end{array}$ & $\begin{array}{l}18 \\
\text { inches }\end{array}$ & $\begin{array}{c}\text { Nitro- } \\
\text { gen }\end{array}$ & $\begin{array}{l}\text { Phos- } \\
\text { phorus }\end{array}$ & $\begin{array}{l}\text { Potas- } \\
\text { sium }\end{array}$ \\
\hline Aibonito.. & 100 & 18.4 & 27.3 & 42.3. & 48.7 & 9.1 & 12.4 & 4.0 \\
\hline Corozal... & 100 & 20.8 & 20.2 & 23.8 & 31.4 & 17.5 & 34.9 & 11.2 \\
\hline 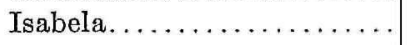 & 100 & 8.8 & 14.0 & 24.6 & 34.2 & 19.1 & 38.2 & 11.2 \\
\hline Mean for all places.... & 100 & 15.6 & 20.5 & 30.3 & 38.1 & 15.2 & 28.5 & 6.3 \\
\hline
\end{tabular}

1 Percentage reduction based on general means for spacing and fertilizer.

${ }^{2}$ Calculations based on yields obtained on fertilizer treatments 1 to 4 .
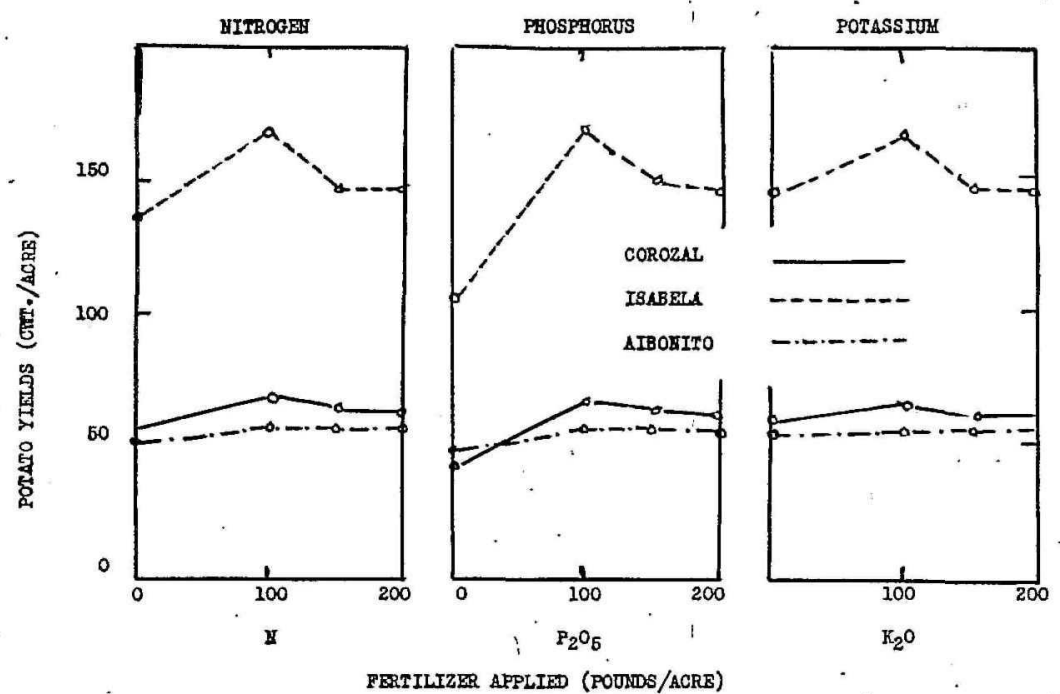

FERIILIZER APPLIED (POUNDS/ACRE)

FIG. 4.-Yield response of the potato to nitrogen, phosphorus, and potassium when used as fertilizer at Aibonito, Corozal, and Isabela, on different soil types.

The reduction for the fertilizer was calculated from the yields of treatments 1 to 4 .

As mentioned above, the greatest reduction in yield occurred when phosphorus was omitted, then nitrogen, and last potassium. The mean reduction in yield for all three experiments produced by the omission of phosphorus was 28.5 percent, for nitrogen 15.2 , and for potassium 6.3 . If the reductions in yields were proportional to the fertilizer requirements it might be concluded that the potato plant, under conditions similar to those in 
this experiment, requires about $21 / 2$ times more nitrogen and about 5 times more phosphorus than potassium.

A high demand for phosphatic fertilizer has been also observed for such crops as tomatoes (4), ${ }^{2}$ tobacco (3), cucumbers (6), corn (10), eggplant (9), and red beans (5), in Puerto Rico. However, sweetpotatoes, also grown on a Lares clay at Corozal, failed to show a high demand for phosphatic fertilizer (4). Sugarcane (7) and pineapples (8) have failed to respond to phosphorus applications in the same soils where the potato and other abovementioned crops have given significant responses to such applications. Sugarcane did respond to phosphorus at Isabela on Coto clay soil. (2) In this soil the highest reduction in potato yields was also observed when phosphorus was omitted (table 4).

Potato production for all three experiments was highest when the plants were 6 inches apart in the row. The mean reduction in yield for all three experiments for the 9-, 12-, 15-, and 18-inch spacings were 15.6, 20.5, 30.3, and 38.1 percent, respectively (see table 4 ). The greatest reduction was observed at Aibonito.

\section{PRACTICAL RECOMMENDATIONS}

FERTILIZER

The response of the potato to fertilizer was greatest for phosphorus, less for nitrogen, and least for potassium. For the potato grown on Lares, Coto, and Juncos clays and similar soils of the Corozal, Isabela, and Aibonito areas where the respective experimental trials were performed, and in order to prevent depletion of the soils, the following fertilizer recommendations for potatoes seem to be in order:

Nitrogen: 50 to 100 pounds of $\mathrm{N}$ per acre.

Phosphorus: 75 to 125 pounds of $\mathrm{P}_{2} \mathrm{O}_{5}$ per acre.

Potassium: 25 to 50 pounds of $\mathrm{K}_{2} \mathrm{O}$ per acre.

The most important item for the farmer to keep in mind is that higher rates of phosphorus than of nitrogen are needed to prevent excessive foliage growth in lieu of high yield in potatoes. The use of an unbalanced fertilizer formula by the farmer will prove to be economically detrimental.

\section{PLANTING DISTANCE}

Normally farmers in Puerto Rico plant potatoes from 12 to 18 inches apart. The results of these experiments show that the distance between plants in the row should be reduced to 6 inches.

\section{SUMMARY}

Combined fertilizer and spacing experiments with potatoes were conducted at Corozal on Lares clay soil, at Isabela on a Coto clay soil, and at Aibo-

${ }^{2}$ Numbers in parentheses refer to Literature Cited, p. 110. 
nito on a Juncos clay soil. The experiments were planted in December 1953 and January 1954. The areas were located at different elevations with variation in soils and climate. The potato variety Kennebec, resistant to blight, was planted. The major results were:

1. Nitrogen did not consistently increase the yield of potatoes significantly.

2. Phosphorus increased the yield of potatoes most.

3. Potassium failed to increase the yield of potatoes significantly.

4. The Coto clay soil gave the highest yield increases attributable to the use of phosphorus fertilizers.

5. The 6-inch planting distance gave the highest potato yields in all three experiments.

6. The interaction between fertilizer and planting distance, or number of potato seed pieces planted per acre, was not significant. As the number of seed pieces increased there was no need for higher rates of fertilizer applications.

7. A highly significant correlation was obtained between number of potato seed pieces planted per acre and yield in all three experiments. This relationship indicates that, as the number of seed pieces increases, the yields also increase.

8. For all three experiments the mean reductions in yield caused by the omission of nitrogen, phosphorus, and potassium were 15.2, 28.5, and 6.3 percent, respectively.

9. Taking yield at 6 -inch spacings as 100 , the reduction in yield at 9 inches was 15.6 , at 12 inches 20.5 , at 15 inches 30.3 , and at 18 inches 38.1 percent.

\section{RESUMEN}

Se llevó a cabo una investigación sobre los abonos y las distancias en cuanto a la siembra de papas en un suelo Lares arcilloso en Corozal, en un suelo Coto arcilloso en Isabela y en un suelo Juncos arcilloso en Aibonito. Las siembras de estos experimentos se efectuaron en diciembre de 1953 y en enero de 1954.

Las.áreas seleccionadas para el establecimiento del trabajo de investigación variaron en elevación, suelos y clima. Se usó la variedad de papa Kennebec, que es resistente al rizón. Los resultados sobresalientes del estudio fueron los siguientes:

1. El uso del nitrógeno no siempre aumentó los rendimaientos significativamente.

2. El uso del fósforo produjo los aumentos mayores en los rendimientos.

3. No se obtuvo aumentos significativos en los rendimientos con el uso de la potasa.

4. El uso del fósforo causó los mayores aumentos en la arcilla Coto. 
5. Las siembras a 6 pulgadas entre plantas en la hilera produjeron los rendimientos más altos en cada uno de los tres experimentos.

6. La interación entre los abonos y las distancias de siembra no fué significativa. Tal parece que la cantidad de abono a aplicarse al suelo en cuanto a la papa, no tiene que aumentarse necesariamente en la práctica, si la distancia de siembra se acorta.

7. Se obtuvo una correlación altamente significativa entre el número de plantas por acre y el rendimiento. La relación indica que el rendimiento aumenta proporcionalmente según se aumentael número de plantas.

8. Los rendimientos se redujeron un 15 , un 28 y un 6 porciento cuando se omitieron en el abono, el nitrógeno, el fósforo y la potasa, respectivamente.

9. Si se toma la distancia de 6 pulgadas como 100, el porciento de reducción en los rendimientos fué 15.6 para la distancia de 9 pulgadas; 20.5 para la de $12 ; 30.3$ para la de 15 , y 38.1 para la de 18.

\section{LITERATURE CITED}

1. Landrau, P. and Samuels, G., The effect of fertilizers on the yield and quality of sweetpotatoes, J. Agr. Univ. P. R. 35 71-87, 1951.

2. - Response of four sugarcane varieties to fertilizers during the first Isabela cycle, 1946-51, J. Agr. Univ. P. R., 38 (2) 73-95, 1952.

3. - Annual Progress Report, Commonwealth project 196, Agr. Expt. Sta. Univ. of P. R. 1954 (unpublished).

4. - The Influence of fertilizers on the yields of Plamar variety of tomatoes on a Coto clay, J. Agr. Univ. P. R., 39 77-83, 1955.

5. Méndez, F., Fertilizer test in the native red beans, Annual Report of the Agr. Exp. Sta. Univ. of P. R. p. 88, 1938-39.

6. Riollano, A., The value of filter-press cake as a fertilizer for vegetable crops, preliminary trials with tomatoes and cucumbers. Proc. Amer. Soc. Hort. Sci. $42547-50,1943$.

7. Samuels, G. and Landrau, P., Annual Report of Agronomy and Horticulture Department, Fiscal Year 1952-53, Agr. Expt. Sta. Univ. P. R. pp. 23-24, 1954.

8. Samuels, G., Landrau, P., and Olivencia, R., Response of pineapple to the application of fertilizers, J. Agr. Univ. P. R. 39 (1) 10, 1955.

9. Serrano, L. A., Annual Report Isabela Substation, Annual Report of the Agr. Expt. Sta. Univ. P. R. Río Piedras, pp. 161-62, 1936-37.

10. - - Fertilizer test with corn, Annual Report of the Agr. Expt. Sta. Univ. of P. R., Río Piedras, p. 43, 1939-40. 